\title{
Features of Foreign Investors Evaluating the Level of Competition in the Banking Market
}

\author{
Nadiia Grebeniuk \\ PhD Student, Department of Business, Trade and Stock Exchanges, Chernivtsi National University of Yuriy \\ Fedkovych, Chernivtsi, Ukraine
}

\section{Jinan Mehdi Mohammed}

MS, Lecturer in Higher College of Technology, Accounting and Finance, Sultanate of Oman

\begin{abstract}
The article substantiates that when developing strategic guidelines for investing, investors from abroad should monitor the Ukrainian banking services market, which allows to assess barriers to entry and exit from the market, the level of saturation of banking services, and also analyze the dynamics of competitors' behavior. A conclusion is drawn about the different levels of competition in different segments of the Ukrainian banking market in the context of state, foreign and private banks. The results of the calculations showed that by the end of 2016, state banks were monopolists in the market of deposit services for individuals, the market of credit services of individuals, the market of commission income; foreign banks in the market of credit services for individuals, private banks in the market of deposit services for legal entities, securities market.
\end{abstract}

Keywords: foreign investors, state banks, banks with foreign capital, private banks, banking services market of Ukraine.

JEL Classification: F3, F21.

(C) The Authors, 2017. This article is published with open access at ARMG Publishing.

\section{Introduction}

Since 2005, when the Austrian group Raiffeisen Int. bought by Ukrainian bank Aval, the domestic banking system is of interest to foreign investors. During 2005-2008, the number of banks with foreign capital increased from 23 to 53, which led to the accumulation of foreign capital in the authorized capital of Ukrainian banks in 2008 at 36.7\%. However, after the financial crisis of 2008-2009 and the significant destructive impact it has inflicted on the financial system of Ukraine, the number of banks with foreign capital, which comes from the EU, has sharply decreased. Between 2012 and 2016, the vast majority of foreign capital in the banking system of Ukraine is capital from Russia, which in the period of intensification of political relations between Russia and Ukraine can not but affect the economic security of the latter. Thus, the restoration of the interest of foreign investors from the EU and the US to the Ukrainian banking market should take place in the context of assessing the new situation that has now emerged in Ukraine.

Over the past two years, the banking system in Ukraine has undergone one of the deepest crises in the years of independence, which has resulted in increased regulatory requirements for banks, the gradual introduction of risk-based oversight and the rapid decline in the number of financial intermediaries, which in most cases performed fake operations to serve interests. As of March 1, 2017, 93 banks functioned in Ukraine, compared to 113 units in 2016 and 151 units in 2015, according to a similar date. In addition to the destructive influence of the factors of the internal financial environment, the stable functioning of the banking system depends to a large extent on a number of external events and processes: the military conflict in eastern Ukraine and annexation of the Crimea, the loss of Ukraine's main trading partner, the volatility of export commodity prices, the recession in the real economy, and also social tension in society. At the same time, foreign investors, as a rule, enter the financial services market during the period of its recovery after prolonged stagnation, so timely identification of this period is an urgent task of financial analysts. Evaluating the level of competition in this case serves as one of the main components of the task. 


\section{Literature review}

The issue of banking competition, approaches to its evaluation and its impact on the efficiency and stability of the functioning of the banking system participants are actively investigated by foreign and domestic scientists and specialists from international organizations.

The conducted empirical studies clearly demonstrate that the higher the level of competition in the banking system, the lower the probability of manifestation of destabilizing factors in the national economy. In particular, researchers at the World Bank Center ( How Does Bank Competition Affect Systemic Stability, 2012.) have found a direct correlation between the level of concentration in the banking market and financial stability in the country, as increased competition encourages banks to take more diversified risks and take rational management decisions.

Banking competition serves as a mechanism for selecting the most rational and effective approaches and techniques of banking business, namely solving a complex of operational, technological, investment and organizational and managerial problems that arise in the activities of each bank. It should be noted that the criterion of efficiency of the bank are indicators of profitability of its activities.

A significant number of jobs (Carletti, 2007; Koetter, 2012) confirms the direct relationship between the level of market banking competition and the efficiency and reliability of the banking institution.

We fully support the view of the authors that the state of competition in the market reflects the efficiency of the functioning of the banking institution in the process of obtaining, maintaining and increasing the competitive position on the market, that is, the ability of the financial institution to meet the needs of consumers and resist negative shocks from the outside.

O. Yakusheva notes that the strengthening of the level of competition in the market of banking services encourages managers of financial institutions to increase the volume of financial resources in innovation, thereby improving their position in the market, expanding the client base and improving the organization of business processes.

It is worth pointing out that it is not necessary to restrict competition in the banking market exclusively between banking institutions, since today there is a significant number of participants in the market that provide related financial, credit and investment services (credit unions, insurance companies, factoring companies, pawnshops, edgefangering platforms etc).

Quite often, in the literature, one can find the statement that the more participants in the market, they will certainly compete for the best positions, as the level of rivalry between them increases. However, according to the theory of quasi-competitive markets, even in a small number of banks (high concentration of banks), the competitive behavior of banks can be observed on the market. The main objective reasons for such a situation in the banking services market are asymmetry of information, an extensive subsidiary and representative network of banks, the bank's entry into the financial and industrial group, the use of innovations, and the improvement of litigation.

\section{Main results of investigation}

The basis of most techniques and approaches to assessing the level of competition in the banking market is the analysis of the market structure. To determine the level of competition in the market, the following characteristics are used (Serheeva, 2003; Zherdetska 2009).

- Indicators of direct influence, reflecting the impact of each individual bank on the market as a whole (Bain, Tobin, Lerner index);

- indexes of indirect influence describing the level of competition in the system as a whole (the HerfindahlHirschman index, the index of concentration, the index of relative concentration, the entropy coefficient, the coefficient of variance of market shares, the Gini coefficient, the Hall-Thyidman index, the H-statistics (the Panzar-Ross model) those others).

Based on the critical analysis of existing approaches, the methodical approach to assessing the level of competition in the market of banking services of Ukraine on the basis of the adaptation of the Herosky model is proposed in the paper, based on which the construction of the econometric model of the dependence of the standardized value of the measure of profit on the standardized value of the degree of concentration 
(Herfindahl index) state, foreign, private banks. In contrast to the existing approaches, the level of competition is proposed to be defined as the parameter of the Herosky regression equation, proportional to the standardized value of the degree of concentration, weighted by the maximum possible value of this parameter, obtained with the maximum values of the degree of profit and the minimum values of the standardized index Herfindahl. Consequently, the proposed approach considers banks as institutions that maximize their profits and compete for consumers by adopting balanced pricing and non-price decisions.

Formalization of the level of competition in the market of banking services based on the adaptation of the model of Herosky has the following form:

$$
\tilde{\pi}_{r}=\alpha \cdot \tilde{N}_{r}+\beta \cdot \widetilde{K}_{r}+\theta \cdot \tilde{\pi}_{r}(t-1)
$$

where $\tilde{\pi}_{r}$ - standardized value of profit; $\mathrm{r}$ - index of participant of Ukrainian banking market; $\tilde{N} F_{r}-$ standardized value of accumulated unpredictable factors in profit-generation models; $\widetilde{K}_{r}-$ the standardized value of the degree of concentration in the context of the r-th participant in the market; $\tilde{\pi}_{r}(t-1)-$ standardized value of profit measure over the previous period; $\alpha, \beta, \theta$-constants that reflect the influence of the factors taken into account in the model of the value of the amount of profit, in particular $\beta$ is a quantitative characteristic of competition in the Ukrainian banking market.

Taking into account a number of accepted hypotheses regarding the formalization of the level of competition in the market of banking services of Ukraine, in particular, the neglect of the lags of delay and the influence of accumulated unrecognized factors in the income model, the econometric model (1) takes the form (2). This form of the model is due to the consideration of the direct proportional dependence of the resultant trait (the profit of a certain group of banks in the market of banking services of Ukraine) from the factor (concentration measure) as a standardized regression equation without a free coefficient.

$$
\begin{aligned}
& \tilde{\pi}_{r}=\beta \cdot \tilde{K}_{r}, \tilde{\pi}_{r}=\frac{\pi_{r}-\bar{\pi}_{r}}{\sigma_{\pi_{r}}}, \widetilde{K}_{r}=\frac{K_{r}-\bar{K}_{r}}{\sigma_{K_{r}}} \Rightarrow \\
& \Rightarrow \frac{\pi_{r}-\bar{\pi}_{r}}{\sigma_{\pi_{r}}}=\beta \cdot \frac{K_{r}-\bar{K}_{r}}{\sigma_{K_{r}}}
\end{aligned}
$$

where $\pi_{r}$ - the value of the amount of profit, calculated on the basis of normalization using the natural method; $\bar{\pi}_{r}$ - arithmetic mean simple profit; $\sigma_{\pi_{r}}$ - mean square deviation of profit; $K_{r}$ - the degree of concentration of the concentration of the market of banking services of Ukraine, is expressed as the value of the indicator Gerfindahl; $\bar{K}_{r}$ - mean square deviation of the degree of concentration in the context of the r-th participant in the market; $\sigma_{K_{r}}-$ mean square deviation of degree of concentration.

Consider the symbols of formula (2), whose values are complex functional dependencies:

$$
\pi_{r}=\frac{p_{r}-\min _{r}\left\{p_{r}\right\}}{\max _{r}\left\{p_{r}\right\}-\min _{r}\left\{p_{r}\right\}}, K_{r}=\left(\frac{k_{r}}{\sum_{r} k_{r}}\right)^{2}
$$

where $p_{r}$ - the value of profit in the context of the r-th participant in the banking services market of Ukraine; $\max _{r}\left\{p_{r}\right\}, \min _{r}\left\{p_{r}\right\}$ - the maximum and, accordingly, the minimum value of profit within the range of data on the considered participants of the Ukrainian banking services market; $k_{r}$-Importance: the volumes of deposits of individuals in the market of deposit services to individuals, volumes of deposits of legal entities in the market of deposit services to legal entities, volumes of loans to individuals in the market of credit services for individuals, volumes of loans to legal entities of the market of credit services to legal entities, volumes of securities in the market securities and non-interest income. 
Taking into account the symbols (3) introduced for the estimation of the degree of profit and the degree of concentration, formula (2) takes the form:

$$
\frac{1}{\sigma_{\pi_{r}}}\left(\frac{p_{r}-\min _{r}\left\{p_{r}\right\}}{\max _{r}\left\{p_{r}\right\}-\min _{r}\left\{p_{r}\right\}}-\bar{\pi}_{r}\right)=\beta \cdot \frac{1}{\sigma_{K_{r}}}\left(\left(\frac{k_{r}}{\sum_{r} k_{r}}\right)^{2}-\bar{K}_{r}\right)
$$

The practical application of the formula (4) for assessing the level of competition in the Ukrainian banking market requires a preliminary collection of statistical data in the dynamics from 2013 to 2016, broken down by groups of state, foreign and private banks. In our opinion, a separate assessment of the level of competition in the context of different groups of Ukrainian banks allows for taking into account the excellent conditions for the organization of banking activities in terms of building internal business processes, access to financial resources, as well as strategies for the development of banks. In the allocation of banks to groups taken into account the decision of the NBU Board of February 10, 2017, No. 76-RSH, according to which:

- state-owned banks - institutions in which the state directly or indirectly owns more than $75 \%$ of the authorized capital.

- banks of foreign banking groups - institutions in which foreign banks or financial and banking groups own a controlling interest;

- private equity banks - institutions in which among the ultimate owners of a qualifying holding are one or more private investors that directly and / or indirectly hold at least $50 \%$ of the authorized capital.

The assessment of the level of competition in the market of banking services of Ukraine is proposed to be carried out in the context of various segments of the activities of financial institutions, namely, lending to corporate and individual clients, attracting deposits from individuals and legal entities, conducting securities transactions, performing commissions (cash and settlement servicing of customers, providing agency services).

Let's move on to assessing the level of competition between groups of Ukrainian banks. An example of the implementation of this methodical approach is proposed to be considered in the context of a group of stateowned banks. So, we will form two arrays of statistical data, the basis for formalizing the econometric model of Herosky: a factor factor - the volume of deposits of individuals and the productive - the profit of state banks (Table 1). Statistical data on various segments of activity by foreign and private banks, as well.

Other statistical data necessary for the formation of the input data array to assess the level of competition in the banking services market is taken on the official website of the National Bank of Ukraine.

Table 1. Dynamics of the volume of deposits of individuals and profit of state banks of Ukraine from 2013 to 2016 , ths. UAH

\begin{tabular}{|c|c|c|c|c|}
\hline \multirow{2}{*}{ Title of the Bank } & \multicolumn{4}{|c|}{ Year } \\
\hline & 2013 & 2014 & 2015 & 2016 \\
\hline \multicolumn{5}{|c|}{ The volume of retail deposits } \\
\hline OSCHADBANK & 35927188 & 36590124 & 53947725 & 69147979 \\
\hline UKREXIMBANK & 17266241 & 21870001 & 24376264 & 24456598 \\
\hline UKRGAZBANK & 5710786 & 6860114 & 10972727 & 13558053 \\
\hline RODOVID BANK & 35181 & 6695 & liquidated & liquidated \\
\hline CALCULATION CENTER & 0 & 0 & 0 & 0 \\
\hline DERZHEMBANK & 0 & 0 & 0 & liquidated \\
\hline UBRD & 0 & 0 & 0 & 0 \\
\hline PRIVATBANK & $\mathrm{x}$ & $\mathrm{x}$ & $\mathrm{x}$ & 151039802 \\
\hline \multicolumn{5}{|c|}{ Volume of profit / loss of banks } \\
\hline OSCHADBANK & 678784 & -8564446 & -12273078 & 468169 \\
\hline UKREXIMBANK & 198616 & -9805548 & -14132383 & -1011106 \\
\hline UKRGAZBANK & 1001973 & -2801124 & 259672 & 293681 \\
\hline RODOVID BANK & -70298 & -266802 & liquidated & liquidated \\
\hline CALCULATION CENTER & 996 & 4896 & -28886 & 2091 \\
\hline
\end{tabular}




\begin{tabular}{|l|c|c|c|c|}
\hline DERZHEMBANK & -2911 & 2135 & 7643 & liquidated \\
\hline UBRD & 94 & -11076 & 570 & -3145 \\
\hline PRIVATBANK & $\mathrm{x}$ & $\mathrm{x}$ & $\mathrm{x}$ & -135309076 \\
\hline
\end{tabular}

On the basis of the data in Table 1, it is necessary to calculate the derivative indicators - the degree of concentration as the indicator Gerfindahl (the square of the share of each bank of the group in the market of deposit services to individuals) on the basis of the application of formula (3). The results of calculations are given in Table 2.

Table 2. The measure of the concentration of deposits of individuals in the dynamics from 2013 to 2016 in the context of a group of state-owned banks

\begin{tabular}{|l|c|c|c|c|}
\hline Title of the Bank & 2013 & 2014 & 2015 & 2016 \\
\hline OSCHADBANK & 0.3716 & 0.3137 & 0.3650 & 0.0717 \\
\hline UKREXIMBANK & 0.0858 & 0.1121 & 0.0745 & 0.0090 \\
\hline UKRGAZBANK & 0.0094 & 0.0110 & 0.0151 & 0.0028 \\
\hline RODOVID BANK & 0.0000 & 0.0000 & liquidated & liquidated \\
\hline CALCULATION CENTER & 0.0000 & 0.0000 & 0.0000 & 0.0000 \\
\hline DERZHEMBANK & 0.0000 & 0.0000 & 0.0000 & liquidated \\
\hline UBRD & 0.0000 & 0.0000 & 0.0000 & 0.0000 \\
\hline PRIVATBANK & $\mathrm{x}$ & $\mathrm{x}$ & $\mathrm{x}$ & 0.3422 \\
\hline
\end{tabular}

After determining the degree of concentration on the market of deposit services for individuals - a factor of the model of Herosky, we proceed to the implementation of the next stage of the methodical approach to assessing the level of competition in the banking services market in Ukraine - the value of the amount of profit as a normalized by the natural method of the value of profit.

The application of the natural method of normalization is due to the nature of the indicator of profit as an indicator of the stimulator, the growth of which occurs as a result of increased competition in the relevant market. So, applying formula (3) on the basis of the data in Table 1, we obtain the value of the effective feature of the Herosky model shown in Table 3.

Table 3. The degree of profit of participants in the market of deposit services for individuals in the dynamics from 2013 to 2016 in the context of a group of state-owned banks

\begin{tabular}{|l|c|c|c|c|}
\hline \multirow{2}{*}{ Name of the Bank } & \multicolumn{3}{|c|}{ Year } \\
\cline { 2 - 5 } & 2013 & 2014 & 2015 & 2016 \\
\hline OSCHADBANK & 0.6986 & 0.1265 & 0.1292 & 1,0000 \\
\hline UKREXIMBANK & 0.2508 & 0.0000 & 0.0000 & 0.9891 \\
\hline UKRGAZBANK & 1,0000 & 0.7140 & 1,0000 & 0.9987 \\
\hline RODOVID BANK & 0.0000 & 0.9723 & liquidated & liquidated \\
\hline CALCULATION CENTER & 0.0665 & 1,0000 & 0.9800 & 0.9966 \\
\hline DERZHEMBANK & 0.0628 & 0.9997 & 0.9825 & liquidated \\
\hline UBRD & 0.0656 & 0.9984 & 0.9820 & 0.9965 \\
\hline PRIVATBANK & $\mathrm{x}$ & $\mathrm{x}$ & $\mathrm{x}$ & 0.0000 \\
\hline
\end{tabular}

Thus, based on the results of the above calculations according to the degree of profit (Table 3 ) and the degree of concentration (Table 2), the level of competition is proposed to determine as a parameter of the Herzog regression equation proportional to the standardized value of the degree of concentration, weighted by the maximum possible value of this parameter, obtained at the maximum values of the measure of profit and the minimum values of the standardized index Gerfindahl:

$$
\begin{aligned}
& \beta_{r}^{*}=\frac{\beta_{r}}{\beta_{\max }} \cdot 100 \\
& \max _{t}\left\{\frac{1}{\sigma_{\pi_{r}}}\left(\frac{p_{r t}-\min _{r}\left\{p_{r t}\right\}}{\max _{r}\left\{p_{r t}\right\}-\min _{r}\left\{p_{r t}\right\}}-\bar{\pi}_{r t}\right)\right\}=\beta_{\max } \cdot \min _{t}\left\{\frac{1}{\sigma_{K_{r}}}\left(\left(\frac{k_{r t}}{\sum_{r} k_{r t}}\right)^{2}-\bar{K}_{r t}\right)\right\}
\end{aligned}
$$

where $\beta_{r}^{*}$ - evaluation of competition in the range from zero (monopoly) to $100 \%$ (perfect competition); 
$\beta_{r}$ - quantitative characteristic (absolute value) of the level of competition as a parameter of the Heros regression equation near the standardized value of the degree of concentration;

$\beta_{\max }$ - theoretically the maximum possible value of the quantitative characteristic (absolute value) of the level of competition, obtained at the maximum values of the degree of profit and the minimum values of the standardized index Gerfindahl.

The consistent application of formula (5) allows obtaining the following results of the assessment of the level of competition among market participants of deposit services for individuals in the period from 2013 to 2016 in the context of a group of state-owned banks (Table 4).

The obtained results show that the most monopolized in the market of deposit services for individuals in Ukraine is a group of state-owned banks, among which, until 2015, Oschadbank took the leading position, and after 2016 - Privatbank. Due to the nationalization of PrivatBank, at the beginning of 2017, the level of competition among private banks increased by 41.78 and 64.61 percentage points, as against 2013 and 2015, respectively. At the same time, the level of competition among foreign banks in the market of deposit services for individuals is decreasing.

Table 4. Estimation of the level of competition among market participants of deposit services for individuals in the dynamics from 2013 till 2016

\begin{tabular}{|l|c|c|c|c|c|c|}
\hline Group of banks & 2013. & 2014 & 2015. & $2016 \mathrm{p}$. & average & Max $\beta_{\max }$ \\
\hline \multicolumn{7}{|c|}{ Absolute values $\beta_{r}$} \\
\hline State & 1.9963 & 0.4281 & 0.4479 & 0.6814 & 1.2906 & 16.0000 \\
\hline Foreign & 57.0348 & 31.1141 & 55.0546 & 36.0320 & 43.0535 & 67.9631 \\
\hline Private & 7.5106 & 6.9935 & 1.9740 & 17.6496 & 9.7749 & 24.2610 \\
\hline \multicolumn{7}{|c|}{} \\
\hline State & Listed on the scale of 0 to $100 \% \beta_{r} *$ & \\
\hline Foreign & 12.4767 & 2.6755 & 2.7992 & 4.2586 & 8.0661 & \\
\hline Private & 83.9202 & 45.7808 & 81.0065 & 53.0170 & 63.3483 & \\
\hline
\end{tabular}

Table 5. Estimation of the level of competition among market participants of deposit services for legal entities in the dynamics from 2013 till 2016

\begin{tabular}{|l|c|c|c|c|c|c|}
\hline Group & 2013 & 2014 & 2015 & 2016 & average & $\max$ \\
\hline \multicolumn{7}{|c|}{ Absolute values } \\
\hline State & 0.8629 & 0.1148 & 0.5369 & 8.5490 & 2.7220 & 2.5571 \\
\hline Foreign & 64.9275 & 35.0690 & 53.6576 & 43.2122 & 27.0229 & 44.7778 \\
\hline Private & 36.0674 & 30.6691 & 6.9035 & 13.9996 & 10.0407 & 19.5360 \\
\hline \multicolumn{7}{|c|}{ Listed on the scale of 0 to $100 \%$} \\
\hline State & 5.8453 & 0.7780 & 3.6369 & 57.9094 & 18.4381 & \\
\hline Foreign & 90.2032 & 48.7210 & 74.5461 & 60.0343 & 37.5427 & \\
\hline Private & 50.1081 & 42.6083 & 9.5909 & 19.4496 & 13.9494 & \\
\hline
\end{tabular}

The bankruptcy of a number of banks, the loss of business of their savings led to a partial flow of capital to state banks as peculiar guarantors of the additional security of their investments. Thus, in 2016, the level of competition among state-owned banks amounted to $57.9 \%$, which is 52.06 percentage points more than in 2013. At the same time, there is an increase in the leading positions of individual private banks, since by the end of 2016 the estimated indicator has decreased by $61.2 \%$ compared to 2013 .

Crisis processes in the banking sector over the past three years, falling rates of economic growth in the country, and lowering business activity and solvency of economic entities are key factors in reducing the volume of loan portfolios of banks of different groups. And so today the key task of banking institutions is to resume lending. That is why competition for borrowers in the domestic market is rather rigid by providing favorable conditions for lending to business representatives.

Table 6. The dynamics of competition between market participants of credit services for legal entities

\begin{tabular}{|l|r|r|r|r|l|l|}
\hline Group & 2013 & 2014 & 2015 & 2016 & average & $\max$ \\
\hline
\end{tabular}




\begin{tabular}{|c|c|c|c|c|c|c|}
\hline \multicolumn{5}{|c|}{ Average values } & & \\
\hline State & 2.4332 & 0.3683 & 0.4593 & 8.1771 & 2.7395 & 2.8355 \\
\hline Foreign & 36.1390 & 22.6434 & 25.7710 & 27.5536 & 16.1107 & 25.6436 \\
\hline Private & 11.3460 & 8.6958 & 2.6709 & 20.6660 & 14.9193 & 11.6596 \\
\hline
\end{tabular}

Table 6 (cont.) The dynamics of competition between market participants of credit services for legal entities

\begin{tabular}{|c|c|c|c|c|c|c|}
\hline Group & 2013 & 2014 & 2015 & 2016 & average & $\max$ \\
\hline \multicolumn{7}{|c|}{ Average values } \\
\hline \multicolumn{7}{|c|}{ Listed on the scale of 0 to $100 \%$} \\
\hline State & 28.9161 & 4.3766 & 5.4583 & 97.1786 & 32.5570 & \\
\hline Foreign & 54.8904 & 34.3923 & 39.1428 & 41.8503 & 24.4700 & \\
\hline Private & 24.4821 & 18.7636 & 5.7632 & 44.5924 & 32.1923 & \\
\hline
\end{tabular}

These tables are clearly demonstrated by the fact that with the nationalization of Privatbank the level of competition among state-owned banks (from 5.5\% to 97.2\%) and private banks of Ukraine increased sharply (from $24.5 \%$ to $44.6 \%$ ). During 2013-2016, the level of competition among banks of foreign banking groups in the market of credit services for legal entities decreased by 23.8 .

According to the calculations, it was found that by the end of 2016 there was a rapid decrease in the level of competition in the lending market of individuals among the state and foreign banks. In particular, Ukrsotsbank, Kredobank, Alfa-Bank were the main providers of loan capital for the population among the institutions of foreign banking groups.

Table 7. Estimation of the level of competition of credit market participants for individuals in the dynamics from 2013 till 2016

\begin{tabular}{|l|c|c|c|c|c|c|}
\hline Group & 2013 & 2014 & 2015 & 2016 & average & $\max$ \\
\hline \multicolumn{7}{|c|}{ Absolute values } \\
\hline State & 3.9389 & 1.1009 & 0.8947 & 0.0379 & 1.4249 & 1.4795 \\
\hline Foreign & 33.5676 & 7.5879 & 11.8719 & 1.0925 & 5.7422 & 11.9724 \\
\hline Private & 13.2602 & 15.6780 & 2.2057 & 11.5804 & 9.6734 & 10.4795 \\
\hline \multicolumn{7}{|l|}{ Listed on a scale from 0 to $100 \%$} \\
\hline State & 38.8396 & 10.8552 & 8.8221 & 0.3738 & 14.0503 & \\
\hline Foreign & 95.1139 & 21.5003 & 33.6390 & 3.0957 & 16.2704 & \\
\hline Private & 37.5728 & 44.4237 & 6.2499 & 32.8131 & 27.4097 & \\
\hline
\end{tabular}

The objective explanation for the sharp decline in competition among state-owned banks in 2016 was the privatization of Privatbank, whose lending policy is focused on the implementation of intensive consumer lending.

With the strengthening of competition and traditional segments of banks (depositing and lending), banks are forced to look for other profitable activities, among which the key role is taken by securities operations. It is worth noting that the activity of banks in the stock market requires a sufficient amount of regulatory capital, an effective system of risk management and an appropriate level of organizational and informational and analytical support of the bank.

Table 8. Estimation of the level of competition of securities market participants in the dynamics from 2013 till 2016

\begin{tabular}{|l|c|c|c|c|c|c|}
\hline \multicolumn{1}{|c|}{ Group } & 2013 & 2014 & 2015 & 2016 & average & max \\
\hline \multicolumn{7}{|c|}{ Absolute values } \\
\hline State & 2.3755 & 0.3172 & 0.4733 & 6.9411 & 4.4383 & 2.9091 \\
\hline Foreign & 19.7340 & 30.3351 & 27.0131 & 21.3366 & 27.0131 & 25.0864 \\
\hline Private & 24.6552 & 143.1403 & 30.8080 & 6.2230 & 30.8080 & 47.1269 \\
\hline \multicolumn{7}{|c|}{ Listed on a scale from 0 to $100 \%$} \\
\hline State & 25.1427 & 3.3574 & 5.0099 & 73.4659 & 46.9760 & \\
\hline Foreign & 8.4496 & 12.9887 & 11.5663 & 9.1358 & 11.5663 & \\
\hline Private & 10.5568 & 61.2891 & 13.1912 & 2.6645 & 13.1912 & \\
\hline
\end{tabular}

At the end of 2016, the level of competition among private banks for the sale of securities decreased by 10.5 percentage points compared to the previous period. 
Relative to an alternative source of revenues for the bank is the provision of related services and the implementation of cash and settlement customer service.

The dynamics of the level of competition in the market of commission income by the group of Ukrainian banks is presented in Table 9.

Table 9. Estimation of the level of competition of market participants of commission income in the dynamics from 2013 till 2016

\begin{tabular}{|l|c|c|c|c|c|c|}
\hline \multicolumn{1}{|c|}{ Group } & 2013 & 2014 & 2015 & 2016 & average & $\max$ \\
\hline \multicolumn{7}{|c|}{ Absolute values } \\
\hline State & 1.7997 & 0.3616 & 0.4026 & 0.1716 & 0.4026 & 0.6276 \\
\hline Foreign & 28.9238 & 14.6069 & 25.7289 & 18.3821 & 25.7289 & 22.6741 \\
\hline Private & 13.1135 & 19.2048 & 3.1710 & 14.3288 & 13.2425 & 12.6121 \\
\hline \multicolumn{7}{|c|}{ Reduced to a scale from 0 to $100 \%$} \\
\hline State & 5.5656 & 1.1182 & 1.2449 & 0.5308 & 1.2449 & \\
\hline Foreign & 96.4614 & 48.7142 & 85.8064 & 61.3047 & 85.8064 & \\
\hline Private & 43.7336 & 64.0482 & 10.5752 & 47.7868 & 44.1640 & \\
\hline
\end{tabular}

The most monopolized in the market of commission income is a group of state-owned banks, since in 2016 the estimated value is $0.53 \%$, which is 5.03 percentage points less than at the beginning of the investigated period. At the same time, competition among foreign and private banks in this segment of the market is moderate.

\section{Conclusions}

Thus, the proposed improved scientific methodological approach and the results of its testing on the activities of domestic banks for the period 2013-2016 confirmed the hypothesis that each segment of the banking services market has its own level of competition, which should be taken into account when developing a strategic map of foreign investors' Ukrainian banking market. In addition, the developed methodological principles allow determining the competitive structure of the industry, which allows foreign investors to form a wellbalanced strategy for choosing an investment object depending on the range of financial services available and the service that is planned to be developed in the light of the prospects of the Ukrainian market.

\section{References}

1. Baumol W. (1982). Contestable Markets: An Uprising in the Theory of Industry Structure. The American Economic Review, 72, 1-15.

2. Beck T. et al. (2006). Bank concentration, competition, and crises: First results. Journal of Banking and Finance, 30, 1581-1603.

3. Carletti, E. et al. (2007). Bank mergers, competition, and liquidity. Journal of Money, Credit and Banking, 39, 1067-1105.

4. DeYoung, R. et al. (1998). Impact of Out-of-State Entry on the Cost Efficiency of Local Commercial Banks. Journal of Economics and Business, 50, 191-203.

5. Geroski P. A. (1988). In pursuit of monopoly power: recent quantitative work in industrial economics. Journal of Applied Econometrics, 3, 107-123.

6. How Does Bank Competition Affect Systemic Stability (2012). The World Bank, Policy Research Working Paper 5981. Retrieved from https:/openknowledge.worldbank.org/bitstream/handle/10986/3267/WPS5981.pdf?sequence=1\&isAllowed=y.

7. Jayaratne, J. et al. (1998). Entry Restrictions, Industry Evolution, and Dynamic Efficiency: Evidence from Commercial Banking, Journal of Law and Economics, 41, 239-273.

8. Koetter, M. et al. (2012). Enjoying the Quiet Life Under Deregulation? Evidence from Adjusted Lerner Indices for US Banks. Review of Economics and Statistics, 94, 462-480.

9. Koskela, E. et al. (2000). Is there a tradeoff between bank competition and financial fragility? Journal of Banking and Finance, 24, 1853-1873.

10. Pokaznyky finansovoi zvitnosti bankiv Ukrainy za period 2013-2016 rr. Natsionalnyi bank Ukrainy [Indicators of financial reporting of Ukrainian banks for the period of 2013-2016. The National Bank of Ukraine]. [Online]. Retrieved from https://bank.gov.ua/control/uk/publish/article?art_id=34661442\&cat_id=34798593. 
11. Rashkovan V. et al. (2015). Concentration of the banking system of Ukraine, Visnyk Natsionalnoho banku Ukrainy, 234, 6-38.

12. Zaruba Yu.O. (2001). Konkurentospromozhnist komertsiinoho banku, Finansy Ukrainy, 2, 22-23.

13. Zherdetska L. V. (2009). Nestrukturni modeli otsinky konkurentsii na rynku bankivskykh produktiv ta posluh Ukrainy [Non-structural models for assessing competition in the market of banking products and services in Ukraine]. Naukovyi visnyk. Odeskyi derzhavnyi ekonomichnyi universytet. Vseukrainska asotsiatsiia molodykh naukovtsiv. Nauky: ekonomika, politolohiia, istoriia, 12 (90), 4-53. 